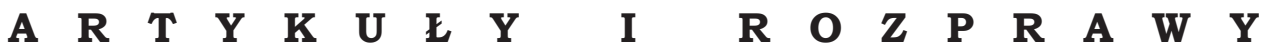

Irena Szczepankowska

DOI: $10.33896 /$ PorJ.2020.4.1

(Uniwersytet w Białymstoku,

e-mail: i.szczepankowska@uwb.edu.pl)

ORCID: 0000-0003-1056-606X

\section{PRACA JAKO POJECIE KONTROWERSYJNE W INTERNETOWYCH DEBATACH POLAKÓW: LINGWISTYCZNA REKONSTRUKCJA MODELI POZNAWCZYCH (NA MATERIALE WYPOWIEDZI Z LAT 2015-2019)}

\section{POLE BADAŃ I ŹRÓDEA MATERIALU JĘZYKOWEGO}

Obserwacje przedstawione w tym artykule wpisują się w plan szerzej zakrojonych badań nad kluczowymi pojęciami, wokół których konstytuuje się i zarazem polaryzuje w ostatnich latach polski dyskurs o gospodarce. Aktywnymi uczestnikami debat toczonych w mediach cyfrowych sa reprezentanci polskiej wspólnoty kulturowo-językowej. Materiał badawczy stanowia komentarze do tekstów dziennikarskich (artykułów, wiadomości, opinii, wywiadów), zamieszczanych w latach 2015-2019 na kilku popularnych portalach internetowych: gazeta.pl, interia.pl, krytyka.polityczna.pl, wyborcza.pl, wpolityce.pl. Taki wybór zmierza do uzyskania szerokiego spektrum poglądów, które można sytuować pomiędzy biegunami „prawicowe” i „lewicowe” lub „konserwatywne” i „liberalne”. Nasza uwaga jest skoncentrowana na anonimowych wypowiedziach internautów, ${ }^{1} \mathrm{w}$ mniejszym zaś stopniu na materiałach kreowanych przez publicystów i ekspertów, którym w udziale przypada jednak ważna rola inicjatorów debaty.

Wybór źródeł nie jest przypadkowy. Rozwój Internetu nadaje dyskursom społecznym nowy wymiar: w największym stopniu przyczynia się do ich demokratyzowania [zob. na ten temat: Czyżewski i in. 2014]. Mimo że obserwatorzy ubolewaja nad niektórymi negatywnymi konsekwencjami tego procesu, nie sposób przecenić roli nowego medium jako forum swo-

1 Cytowane wypowiedzi, chociaż sygnowane różnymi pseudonimami komentatorów, sa traktowane jako fragmenty dyskursu i lokalizowane poprzez odwołanie do inicjującego materiału dziennikarskiego, pod którym zostały zamieszczone (zob. rozwiązanie skrótów nazw odsyłających do odpowiedniej strony internetowej - na końcu niniejszego artykułu). Często odtwarzane w badanym dyskursie i zapisane tutaj kursywa pojedyncze słowa, wyrażenia i zwroty nie sa lokalizowane. Cytaty poddano niezbędnej korekcie językowej (głównie graficznej), w żaden sposób nieingerującej w ich treść. 
bodnej i powszechnie dostępnej interakcji. Zwiększyły się istotnie dzięki tej wymianie możliwości negocjowania (tu i teraz) znaczeń symboli językowych, a więc kwestionowania, modyfikowania i uzgadniania różnych „map pojęciowych” w danej grupie uczestników dyskursu. Internetowa logosfera jest nie tylko generatorem mentalnego chaosu, ideologicznych konfliktów i mowy nienawiści, lecz także kuźnią idei, polem konfrontacji różnych modeli poznawczych, szkołą ich prezentowania i uzasadniania oraz warsztatem doskonalenia językowych środków przekazu.

\section{PRZEDMIOT, CEL I METODA BADAŃ}

Na poziomie metajęzyka lingwistycznego „kluczowe pojęcia” należy odróżnić od „słów kluczy” mimo nierozerwalnego związku jednostek myśli i mowy: słowa klucze sa w wypowiedziach najczęściej używanymi leksykalnymi „węzłami dostępu” [por. Langacker 1987, 163] do sieci pojęć z danego obszaru wiedzy mówiących. Pojęcia takie można uważać za „centralne punkty" [por. Wierzbicka 1997, 16-17] w organizacji wiedzy danej wspólnoty dyskursywnej. W prezentowanym tutaj podejściu badawczym traktujemy węzłowe kategorie jako przedmiot sporu, co oznacza, że ich kognitywna wartość podlega negocjowaniu. Niemieccy badacze [Stötzel, Wengeler 1995] nazywają takie pojęcia kontrowersyjnymi (Controverse Begriffe): kluczowe idee odznaczaja się najwyższym stopniem kontrowersyjności, a co za tym idzie, sa najczęściej sytuowane w pozycji tematu wypowiedzi. Odnosza się do wartości istotnych dla danej grupy i sa podatne na ideologiczne profilowanie. W analizowanym tutaj materiale pojawiaja się jako przedmiot sporu organizujacego komentarze na temat spraw gospodarczych. Wokół pojęć centralnych budowane sa „wyidealizowane modele poznawcze” - Idealized Cognitive Models (w skrócie ICM) według określenia G. Lakoffa [1987] - służące porządkowaniu wiedzy i uzasadnianiu ideologicznego stanowiska uczestników dyskursu.

Przedmiotem podjętych badań jest rekonstrukcja aktualizowanych w dyskursie modeli poznawczych (ICM-ów), a zasadą metodologiczna analiza semantyczna często odtwarzanych kolokacji, a zwłaszcza słów kluczy przywołujaccych wyodrębnione pojęcia centralne i pełniących zarazem rolę swoistych "słów magnesów” [Kita 2014], które przyciagają uwagę internautów i staja się zarzewiem sporu. Identyfikacja pojęć kontrowersyjnych pozwala na wydzielenie fragmentów dyskursu jako serii komentarzy, które sa najbardziej reprezentatywne dla danego wątku (szczegółową analizę takich fragmentów zaleca Jäger [2004, 72]). Semantyczno-pragmatyczna analiza wypowiedzi na temat gospodarki pozwala uchwycić profile kluczowych pojęć i zrekonstruować ICM-y właściwe danej grupie dyskutujacych.

Jednym $z$ kluczowych symboli odnoszących się do pojęć kontrowersyjnych w polu tematycznym 'gospodarka jest praca. Na początku 
lat 90. XX wieku Polacy mieli jeszcze dość stabilne wyobrażenie aktywności zwanej praca [Mazurkiewicz-Brzozowska 1993], a definicja nazwy w SJPDor odzwierciedlała powszechnie podzielane wyobrażenie kategorii:

praca 'świadoma, celowa działalność człowieka zmierzająca do wytworzenia, wyprodukowania określonych dóbr materialnych lub kulturalnych, będąca podstawą i warunkiem istnienia i rozwoju społeczeństwa ludzkiego; wykonywany zawód, zajęcie, zatrudnienie, robota'.

Transformacja ustrojowa w Polsce, dokonana w ostatnich dziesięcioleciach, właczyła kraj w globalne procesy zachodzace w gospodarce kapitalistycznej. W szczególności doświadczenie masowego bezrobocia i poszukiwania pracy na wolnym rynku przewartościowało tradycyjne modele poznawcze, w tym wyobrażenie kryjace się za słowem praca. W naukach społecznych symbol ten jest dziś przez niektórych polskich badaczy, nawiazujących do koncepcji filozofa i teoretyka dyskursu Ernesto Laclau, uznawany za „pusta znaczaca”" [zob. Stańczyk 2013, 50-53], czyli jednostkę językowa niemajacca aktualnie uzgodnionej, powszechnie przyjętej referencji i będacca w zwiazku z tym obiektem ideologicznej rywalizacji w dyskursie. Ponieważ $z$ lingwistycznej perspektywy trudno zaakceptować istnienie pustych symboli, uznajemy takie słowa jak praca za klucze dostępu do pojęć będacych w swoistej przebudowie. Nowe znaczenia kształtuja się w ramach odmiennych wyobrażeń różnych grup uczestników medialnej debaty, a liczne konotacje kluczowego słowa, przywoływane w wypowiedziach, wskazuja na polaryzację ICM-u „praca” w świadomości Polaków.

Żeby zrozumieć dzisiejsze kontrowersje zwiazane z pojmowaniem pracy, wystarczy spróbować odpowiedzieć na pytania o istotne (definicyjne) atrybuty kategorii. Czy każda praca jest wartością: indywidualna, społeczna, służaca rozwojowi cywilizacyjnemu? Jak w tych aksjologicznych ramach umieścić doświadczenie pracy na umowie śmieciowej (w opozycyjnym systemie znaczeń określanej jako elastyczna forma zatrudnienia) lub pracy szkodliwej, np. niszczącej środowisko naturalne? Czy wartość pracy mierzy się wysokością zarobku, tj. wyceną na rynku, czy może społeczną użytecznościa, a więc czy praca nieprzynoszacca dochodu jest wartościowa i czy jest w ogóle praca, skoro o tych, którzy nie zarabiaja (nie sa zatrudnieni), mówi się, że sa bezrobotni (niepracujacy)? Praca jest prawem jednostki, obowiazkiem moralnym czy jedynie przymusem ekonomicznym? Czy polega dziś przede wszystkim „na wytwarzaniu, produkowaniu określonych dóbr materialnych lub kulturalnych", jak zapisano w cytowanej wyżej definicji? A może dla przeciętnego mieszkańca Europy, który tak często słyszy o „przenoszeniu produkcji wszystkiego do Chin”, typowa praca fizyczna to już dzisiaj głównie świadczenie usług, a nie wytwarzanie i produkowanie?

Analiza reprezentatywnych fragmentów dyskursu $-z$ uwzględnieniem aktualizowanej w nich kategorii poznawczej oraz uwarunkowań pragmatycznych, kulturowych, a zwłaszcza ideologicznych, wyrażanych sąów - może pomóc odpowiedzieć na postawione wyżej pytania. 


\section{PROFILOWANIE KLUCZOWEGO POJECIA <PRACA> W DYSKURSIE ZWOLENNIKÓW I KRYTYKÓW KAPITALIZMU}

Obserwatorzy dyskursu politycznego sa zgodni, że jego najbardziej wyrazistym wyznacznikiem jest ideologiczna polaryzacja uczestników [Kłosińska 2016]. Można ją uznać za dowód ujawnionych w sporze podziałów społecznych. Kontradyktoryjność jest też podstawową cechą debaty o gospodarce, toczacej się w Polsce od długiego czasu w ramach narzucanych zasadniczo przez kapitalistyczna formację, w której ścieraja się jednak rozmaite stanowiska ideowe. Antagonizmy maja związek zarówno $z$ doraźnymi, pragmatycznie motywowanymi interesami jednostek i grup społecznych, jak i w dużym stopniu z postawami moralnymi [zob. Lakoff 2017], przyjmowanymi - mniej lub bardziej świadomie - przez zwolenników różnych opcji światopoglądowych.

Analiza treściowa serii komentarzy internetowych pozwala wyznaczyć oś sporu pomiędzy dwiema grupami antagonistów, którzy posługuja się odmiennymi kategoryzacjami rzeczywistości i kontekstowymi ramami pojęciowymi, wpływajacymi na różne wartościowanie tych samych zjawisk. Środowiska te maja swoich aktywnych reprezentantów oraz rzesze stronników i przeciwników. Jedna grupa skupia zwolenników kapitalizmu (dalej skrót: ZK), druga - jego krytyków (KK). Pierwsi zazwyczaj deklaruja poparcie dla partii prawicowych i gospodarki wolnorynkowej - to prawicowcy i liberałowie, przez przeciwników nazywani także neoliberałami lub korwinistami (od nazwiska polityka propagujacego w Polsce radykalny model kapitalizmu Janusza Korwin Mikkego). Drudzy z kolei, identyfikujacy się politycznie jako lewica (lewicowcy) lub socjaliści, sa w komentarzach pierwszej grupy mianowani lewakami lub (neo-/post-)komunistami. Dyskurs krytyków kapitalizmu, uznawanego do niedawna za system „bezalternatywny", jest w Polsce dość świeżej daty. Grupę KK spaja retoryka sprzeciwu wobec dominującego modelu społeczno-gospodarczego, dzieli natomiast dość szeroki zakres poglądów uczestników: od zwolenników kapitalizmu z ludzka twarza (takiego, jaki jest obserwowany w krajach skandynawskich) przez umiarkowanych socjalistów, opowiadajacych się za społeczna gospodarka rynkowa poddana nadzorowi państwa, do reprezentantów radykalnej lewicy, w tym tych, którzy z nostalgia wspominaja PRL i nie unikają odniesień do myśli marksistowskiej. Wszystkich łączy krytyka istotnych założeń ideowych, praktyk i skutków wdrażania w Polsce (po roku 1989) reguł kapitalizmu w postaci neoliberalnej.

Wyodrębnione opcje ideowe ZK i KK różni nie tyle zasób pojęć, ile ich hierarchia i profilowanie, tj. podkreślanie wybranych aspektów w różnych domenach. Inna jest pozycja takich wartości kolektywnych jak praca w ideologii wyznawanej przez każda $z$ grup i w różny sposób kategorie te sa modelowane. Warto zacytować najpierw reprezentatywne dla tego wątku fragmenty dyskursu (szersza dokumentacja nie mieści się w ograniczonych ramach artykułu): 
[ZK1] Europa ginie w populizmie socjalnym. (...) Bo dobrobyt bierze się z pracy, a nie $z$ socjalu. Jeżeli ktoś ma niskie kwalifikacje, to konkuruje $z$ tysiącami takich o niskich kwalifikacjach, a jak ma wysokie umiejętności to wtedy może dostać większa płacę, bo mniej ma konkurentów, a jego praca przynosi większa wartość dla firmy. O płacy decyduje rynek, a nie chciejstwa związków zawodowych lub mas ludowych. Kapitalizm to jest przyszłość rozwoju, a nie skanseny socjalizmu [W-2015].

[ZK2] Po pierwsze „bez pracy nie ma kołaczy” - pracujesz, masz, żyjesz. Brak zasiłków - musisz mieć motywacje utrzymania rodziny. Po drugie wszystkim doświadczonym przez los - pomoc, ale tylko przez fundacje (...). W ludziach jest potrzeba dzielenia sie - do tego nie potrzeba Państwa i chmary urzędników. Po trzecie likwidacja durnych 95\% przepisów - wtedy urzędasy same będa musiały iść do zwykłej pracy. Po czwarte wolność dla ludzi - możesz robić wszystko, ale do granicy wolności innego człowieka [In-2019].

[KK1] W historii nie brakuje przykładów ludzi, którzy ciężko pracowali przez całe życie i z ledwością byli w stanie wykarmić swoje rodziny. Nadwyżka, jaka wytwarzali, zawsze zaś wpadała w ręce klas panujących. Co więcej, to właśnie ci, którzy korzystali z tego systemu, sami mamili innych opowieściami o „uczciwej” i „ciężkiej” pracy. Nakładali moralna pomadę na niesprawiedliwy system, który wyniósł ich samych ponad innych [KP-2017a].

[KK2] Marks opisał zjawisko alienacji pracy jako pozbawienia pracownika podstawowego prawa ludzkiego do (...) rozwijania swoich możliwości (...), a które zamiast tego czyni z pracownika niewolnika, zmuszonego nierzadko wykonywać coraz bardziej nieludzkie żądania pracodawcy. Wyzysk w kapitalizmie wcale się nie skończył i praca wciąż pozostaje wyalienowana, jak wielokrotnie opisywana harówa w magazynach Amazona w Polsce albo w szwalniach w Bangladeszu [W-2019].

Nie każda praca, lecz tylko praca zarobkowa, wykonywana na wolnym rynku, zajmuje miejsce centralnej wartości w swoistym światopoglądzie ekonomicznym reprezentantów grupy ZK. Jest pojmowana jako indywidualny wysiłek każdego człowieka, przynoszacy dochód, który pozwala zaspokoić podstawowe potrzeby biologiczne, zarobić na życie (i „utrzymanie rodziny"- ZK2), a z czasem dorobić się majątku, jak głosi często przywoływane hasło: Oszczędnościa $i$ praca ludzie się bogaca. Zysk z pracy (dochód, zarobek) ma wartość motywacyjna i jest nagroda za wysiłek, dzięki któremu pracujacy ma zapewniony dobrobyt materialny, a w dalszej kolejności inne dobra (niematerialne): wolność, godność, szacunek społeczny, bezpieczeństwo. Praca zarobkowa poszczególnych obywateli przynosi korzyść całemu społeczeństwu. „Wartość, czyli bogactwo, bierze się z pracy” [W-2019, por. ZK1] - podkreślają ci, którzy najczęściej określają siebie samych jako ludzi ciężko pracujacych: „Jestem libertarianinem. Wierzę, że tylko ciężka praca, uwolniona od państwowych kajdan może przynieść dobrobyt" [WP-2018]. Kolokacja ciężka praca wskazuje na najważniejszy profil pojęcia kluczowego w dyskursie ZK: praca prototypowo wiąże się $z$ wysiłkiem fizycznym. Pracujacy mówią o sobie, że haruja $w$ robocie, tyraja po nocach, zarzynaja sie $w$ pracy, zasuwaja $w$ pocie czoła. Powtarzalne frazy podkreślają mozół wiążacy się z praca zarobkowa i ujmuja ja w ramę przykrego obowiazku, który jest jednak etycznie i pragmatycznie 
usankcjonowany, co wyrażaja często odtwarzane [por. ZK2] przysłowia i zarazem aksjomaty moralne: Kto nie pracuje, ten nie je; Bez pracy nie ma kołaczy. Stosunek do pracy jest podstawa pozytywnej samoidentyfikacji grupy ZK, której członkowie to nie tylko pracownicy (rekrutujący się raczej z wyższej klasy średniej w przeciwieństwie do pospolitych średniaków, zagrożonych ekonomiczna i klasowa degradacja), lecz i mali przedsiębiorcy, w tym tzw. samozatrudnieni, wykorzystujaccy siłę rąk, inteligencję i spryt, by sprostać konkurencji na rynku pracy. $Z$ czasem ci zaradni i pracowici wolnorynkowi gromadzą i inwestuja kapitał, tj. podejmują ryzyko i jako pracodawcy zapewniaja (organizuja) pracę innym.

Krytycy kapitalizmu swój przekaz kieruja $z$ kolei nie tyle do przedsiębiorców, ile do pracowników najemnych, ubożejacej klasy średniej, zwłaszcza pracowników sfery budżetowej, bezrobotnych i prekariuszy. W dyskursie KK aktywność (niekoniecznie zarobkowa) może być wartościowa, „pod warunkiem, że jest to praca, w której człowiek się odnajduje, sprawia mu ona satysfakcję, jest pożyteczna" [W-2019]. Nie każde zatem tego rodzaju działanie jest waloryzowane dodatnio: „dużo jest na świecie pracy zbędnej, a nawet szkodliwej” [KP-2017]. W szczególności praca najemna bywa postrzegana $\mathrm{w}$ ramie społecznej alienacji, niesprawiedliwości i wyzysku (jak w wypowiedziach KK1 i KK2), a co za tym idzie, nie jest przesłanka do przyznawania lub odbierania komukolwiek prawa do godnego życia. Nie jest nawet koniecznym warunkiem jednostkowego czy społecznego dobrobytu, gdyż w kapitalizmie, zdaniem jego krytyków, o dochodach jednostek i zbiorowości często decydują czynniki niemające nic wspólnego z ciężka (uczciwa) pracą. Bogactwo może wynikać $z$ renty kapitałowej, przewagi konkurencyjnej związanej $z$ monopolem, dziedziczenia majątku, posiadania bogactw naturalnych (np. ropy i gazu), a także $z$ modelu organizacji społecznej (kultury). Wszystko to może się zarówno przyczyniać do dobrobytu całego społeczeństwa, jak i być przyczyna nierówności dochodowych - niesprawiedliwych właśnie dlatego, że nie zależą od indywidualnego wysiłku. Wymagana jest zatem państwowa dystrybucja wyrównawcza, za którą opowiadają się również uznawane przez KK autorytety naukowe [Stiglitz 2015]. Dlatego państwo socjalne jest sytuowane najwyżej w hierarchii wartości. Praca bywa, owszem, cenna w perspektywie indywidualnej i społecznej, ale tylko taka, która jest twórcza, sprzyja samorealizacji pracownika, zapewnia mu poczucie godności i bezpieczeństwa oraz jest sprawiedliwie wynagradzana - sa to najważniejsze aspekty wyidealizowanego modelu pracy w poglądach krytyków kapitalizmu.

Tym, którzy pracę stawiają w centrum własnego systemu aksjologicznego (ZK), jej wartość kojarzy się wyłącznie $z$ wysokością dochodu: „praca i dobra płaca dają ludziom godność” [In-2019a], a nie $z$ poziomem satysfakcji, przyjemności czy samorealizacji. Dlatego skarga prekariusza: „Nie chcę wykonywać bezsensownej, wyczerpującej, do tego nisko płatnej pracy - i nie mam zamiaru się tego wstydzić" [KP-2018a] jest niezrozumiała dla zwolenników kapitalizmu, którzy uważają nawet, że im bardziej 
wyczerpujace i nieprzyjemne sa wykonywane obowiązki, tym większa zasługe (moralna) ma pracujacy. Musi bowiem wykazać się silną wolac i samodyscyplina, by zapracować na swoje utrzymanie i nie domagać się pomocy od innych:

No niestety, bez pracy nie ma kołaczy (...) Zdrowi mężczyźni powinni zasuwać w pocie czoła. Całe studia (dzienne) ciężko pracowałem fizycznie i korona mi z głowy nie spadła [KP-2018a].

Gospodarka wolnorynkowa jest pozytywnie oceniana jako przestrzeń, w której o sukcesie decydują osobiste przymioty ludzi (zdolności, kompetencje, wola), nade wszystko zaś wysiłek wkładany w pracę, a nie na przykład koncesje polityczne czy znienawidzone przez ZK przywileje socjalne. $Z$ tego punktu widzenia podatki sa często interpretowane jako: zabieranie / zżeranie (połowy) zarobków, okradanie przez państwo ciężko pracujacych, równe dzielenie biedy, karanie pracowitych po to, by wesprzeć leniwych. ${ }^{2}$ Postulat niskich (i liniowych) podatków uzasadniaja zatem polscy zwolennicy kapitalizmu tym, że prywatne podmioty potrafia lepiej niż administracja państwowa - także $z$ pożytkiem dla całego społeczeństwa, a zwłaszcza jego słabszej części [zob. komentarz ZK2] - inwestować zyski i w ten sposób przyczyniać się do wzrostu gospodarczego. Podobnych argumentów używaja sławni orędownicy ekonomii liberalnej [Friedman 2018]. Zasiłki dla ubogich (potocznie zwane socjalem) sa prezentowane jako populistyczne i demoralizujace, przede wszystkim dla samych beneficjentów, którzy dostaja wszystko za darmo. Ci tzw. zasiłkowicze sa przyzwyczajani do bierności i szukania łatwiejszych niż praca zarobkowa (także nielegalnych) sposobów zdobycia pieniędzy; często też przyjmuja postawę roszczeniową (graja pokrzywdzonych), mówiąc: „ja jestem biedny i mnie się należy" [KP-2017a]. W dyskursie ZK kwituje się ją fraza przywołujaca realia PRL-u: Czy się stoi, czy się leży, dwa tysiace się należy. Głoszonym wówczas hasłom: Każdemu według potrzeb i Wszyscy maja równe żołądki zwolennicy wolnego rynku przeciwstawiają dyrektywę Każdemu według jego pracy sankcjonujaca nierówności dochodowe: bogactwo jednych i ubóstwo innych, nawet takie, które prowadzi do niemożności zaspokojenia podstawowych potrzeb: Nie pracujesz - nie jesz. Nie ma usprawiedliwienia dla bezrobotnych, zdaniem zwolenników kapitalizmu, co wiąże się $z$ przekonaniem, że w gospodarce wolnorynkowej zawsze można znaleźć pracę - jeśli nie dobra, to przynajmniej znośną; jeśli nie tutaj, to gdzie indziej (hasło Zmień prace, weź kredyt stało się niemal przysłowiowa recepta dla niezadowolonych ze swojej sytuacji życiowej). Stosunek do pracy jest dla ZK kluczowym kryterium oceny przeciwników

2 Takie stanowisko łączy polskich zwolenników gospodarki kapitalistycznej $z$ amerykańskimi konserwatystami (wyznawcami „moralności surowego ojca”), którzy również postrzegają wysokie podatki dla bogatych i państwowy system dystrybucji jako karanie pracowitych [zob. Lakoff 2017, 190]. 
ideologicznych, postrzeganych jako obrońcy tych, którzy nie garną się do pracy, czyli leni, nierobów, nieuków, obiboków, trutni, lewusów, meneli, darmozjadów, pasożytów, roszczeniowców - zasób podobnie stygmatyzujących określeń jest w dyskursie ZK imponująco rozbudowany. Pogardliwie nacechowane sa także określenia tych, którzy zdaniem tej grupy dyskutantów mają lekka prace, przeważnie opłacana $z$ budżetu państwa (przyssani do państwowej kasy, budżetówka), czyli z podatków wszystkich ciężko pracujacych. Wydźwięk zdecydowanie piętnujący ma kwalifikacja humaniści; potępiani sa także nauczyciele (maja długie wakacje), pracownicy administracji i banków (białe kolnierzyki, urzędasy). Zwolennicy kapitalizmu preferują wykształcenie techniczne, ścisłe i praktyczne: „Dobrobyt państwa buduje technika i inżynieria, a nie urzędnicy, humaniści i imigranci na socjalu" [In-2018]. Wykluczonymi ze wspólnoty ludzi pracy i zaliczanymi do wyznawców ideologii lewicowych sa w szczególności klienci opieki społecznej, a więc ci, którzy sobie nie radza - nie ze względu na obiektywne upośledzenie (choroba, kalectwo, nieszczęście losowe), lecz niechęć do ciężkiej pracy.

W wypowiedziach przeciwników [KK] najczęściej przywoływana ramą interpretacyjna, w której wyraża się krytyczny stosunek do kapitalistycznego modelu pracy, sa natomiast pojęcia wyzysku i niewolnictwa. W polu semantycznym tych kluczowych symboli mieszcza się także inne wartościujacce słowa i kolokacje, takie jak: harówa, polskie obozy pracy, neoliberalny kołchoz, tania siła robocza, praca na umowie śmieciowej, pracować za miskę ryżu, wykorzystywać roboli. Pogardliwe i nienawistne nominacje symbolizuja pracodawców (zwłaszcza polskich): Janusze biznesu, byznessmani (określenie to powstało $z$ kontaminacji nazw biznesmeni i esesmani), wyzyskiwacze, krwiopijcy. Mówi się o alienacji pracy, „która czyni z pracownika niewolnika" [KK2] oraz o potrzebie państwowej (Kodeks pracy) i branżowej (zwiazki zawodowe) ochrony, która w Polsce, zdaniem dyskutantów, powinna być zdecydowanie wzmocniona „by pracownicy przestali być niewolnikami” [W-2018]. W dyskursie KK zakorzenione sa już takie kolokacje jak godziwa płaca minimalna czy gwarancja pracy; mówi się nawet o wprowadzeniu „bezwarunkowego dochodu gwarantowanego" [In-2019], który miałby zaradzić problemom zwiazanym $z$ automatyzacja pracy. Nie praca zatem, a uwolnienie od przymusu jej świadczenia jest dla socjalistów warunkiem godności człowieka. W zaprzęgnięciu do różnych robót sztucznej inteligencji widzą oni szansę na wyzwolenie pracowników najemnych, podczas gdy kapitaliści w robotyzacji upatruja okazji do zredukowania osobowych kosztów pracy. Zdaniem KK ciężkie, żmudne, mechaniczne zajęcia powinny być efektywnie zautomatyzowane, a jeśli musza być wykonywane przez ludzi, to tylko za godziwym wynagrodzeniem, by ci mogli jak najszybciej się wyzwolić i na drodze edukacji zmierzać do zajęcia sie praca umysłowa - taki profil pracy jest pożadany i godny człowieka w XXI wieku: „Dbajmy o edukację naszych dzieci, bo w ich czasach będzie prawie wyłącznie praca umysłowa. I dobrze!” [G-2019a]. 


\section{MODELE POZNAWCZE ZBUDOWANE WOKÓE POJĘCIA <PRACA> W DYSKURSIE ZWOLENNIKÓW I KRYTYKÓW KAPITALIZMU}

Przedstawiona wyżej analiza profili pojęciowych < pracy> w ideologicznie spolaryzowanym dyskursie o gospodarce, który umożliwiaja i stymuluja cyfrowe media, pozwala wyodrębnić dwa wyraziste ICM-y zwiazane z poglądami najważniejszych grup uczestników tego dyskursu: zwolenników kapitalizmu i jego krytyków. W zwiazku $z$ tym na rekonstruowane modele poznawcze składają się zespoły aksjomatów służące danej grupie nie tylko do pozytywnej autoidentyfikacji, ale także do rozpoznawania przeciwników jako wyznawców negatywnie kwalifikowanej ideologii. ICM obejmuje model idealny (postulowany) oraz niepożądany (odrzucany) przez dana grupę jako właściwy przeciwnikom. Poniżej prezentowany opis modeli poznawczych zmierza do ukazania wysoce kontrowersyjnego charakteru kluczowego pojęcia < praca> w internetowych debatach Polaków.

Zrekonstruowane ICM-y nie sa statycznymi konstruktami, lecz podlegają modyfikacjom wynikającym $z$ konfrontowania $w$ dyskursie różnych składników tych biegunowo przeciwstawnych wyobrażeń. Obserwacje innych źródeł i grup respondentów być może przyczyniłyby się do większego zróżnicowania i zarazem uszczegółowienia charakterystyki przedstawionej w poniższej tabeli, która dostarcza swego rodzaju matrycy kognitywnej.

\begin{tabular}{|c|c|c|c|}
\hline \multicolumn{2}{|c|}{$\begin{array}{c}\text { Praca w dyskursie } \\
\text { zwolenników kapitalizmu }\end{array}$} & \multicolumn{2}{|c|}{$\begin{array}{c}\text { Praca w dyskursie } \\
\text { krytyków kapitalizmu }\end{array}$} \\
\hline $\begin{array}{c}\text { Model służący } \\
\text { identyfikacji } \\
\text { przeciwników }\end{array}$ & $\begin{array}{l}\text { Model służący } \\
\text { autoidentyfikacji }\end{array}$ & $\begin{array}{l}\text { Model służący } \\
\text { autoidentyfikacji }\end{array}$ & $\begin{array}{l}\text { Model służący } \\
\text { identyfikacji } \\
\text { przeciwników }\end{array}$ \\
\hline \multicolumn{4}{|c|}{ domena atrybutów } \\
\hline \begin{tabular}{|l} 
- umysłowa, \\
czyli lekka, \\
łatwa \\
i przyjemna \\
- wykonywana \\
przez \\
humanistów \\
- organizowana \\
przez \\
państwo \\
- zapewniająca \\
pracownikowi \\
wiele wolnego \\
czasu
\end{tabular} & $\begin{array}{l}\text { - zarobkowa } \\
\text { - ciężka, fizyczna, } \\
\text { czasochłonna } \\
\text { - realizowana na } \\
\text { wolnym rynku } \\
\text { - bazujacca na } \\
\text { umiejętnościach } \\
\text { praktycznych } \\
\text { - wymagająca od } \\
\text { pracowników } \\
\text { poświęceń } \\
\text { (np. ograniczenia } \\
\text { udziału w życiu } \\
\text { rodzinnym) }\end{array}$ & \begin{tabular}{|l} 
- dobrowolna \\
aktywność (nie \\
tylko zarobkowa) \\
dorosłych \\
ludzi służaca \\
dobru jednostki \\
i społeczeństwa \\
- zgodna \\
z zainteresowaniami \\
pracownika \\
- zapewniająca \\
przyjemność \\
z rozwijania \\
umiejętności \\
i talentów
\end{tabular} & $\begin{array}{l}\text { - żmudna, } \\
\text { bezsensowna, } \\
\text { często } \\
\text { niewolnicza, } \\
\text { uragajacca } \\
\text { godności } \\
\text { człowieka } \\
\text { - niezapewniająca } \\
\text { dochodu na } \\
\text { zaspokojenie } \\
\text { podstawowych } \\
\text { potrzeb } \\
\text { - niezostawiajacca } \\
\text { pracownikom } \\
\text { czasu na inne } \\
\text { aktywności }\end{array}$ \\
\hline
\end{tabular}




\begin{tabular}{|c|c|c|c|}
\hline \multicolumn{2}{|c|}{$\begin{array}{c}\text { Praca w dyskursie } \\
\text { zwolenników kapitalizmu }\end{array}$} & \multicolumn{2}{|c|}{$\begin{array}{c}\text { Praca w dyskursie } \\
\text { krytyków kapitalizmu }\end{array}$} \\
\hline $\begin{array}{c}\text { Model służący } \\
\text { identyfikacji } \\
\text { przeciwników }\end{array}$ & $\begin{array}{l}\text { Model służący } \\
\text { autoidentyfikacji }\end{array}$ & $\begin{array}{l}\text { Model służący } \\
\text { autoidentyfikacji }\end{array}$ & $\begin{array}{l}\text { Model służący } \\
\text { identyfikacji } \\
\text { przeciwników }\end{array}$ \\
\hline \multicolumn{4}{|c|}{ domena funkcji } \\
\hline $\begin{array}{l}\text { - służy przy- } \\
\text { jemności } \\
\text { i bezpieczeń- } \\
\text { stwu so- } \\
\text { cjalnemu } \\
\text { jednostki } \\
\text { - często bywa } \\
\text { nieużyteczna } \\
\text { dla społe- } \\
\text { czeństwa } \\
\text { (np. ,ja- } \\
\text { łowe filozo- } \\
\text { fowanie”) } \\
\text { lub nawet } \\
\text { szkodliwa } \\
\text { (polityka, } \\
\text { biurokracja) }\end{array}$ & \begin{tabular}{|c|} 
- stanowi źródło do- \\
chodu zapewniają- \\
cego podstawowa \\
egzystencję (i z cza- \\
sem bogactwo) jed- \\
nostce i rodzinie \\
- jest najważniejszym \\
warunkiem dobro- \\
bytu materialnego \\
społeczeństwa \\
- stanowi podstawę \\
wszelkich praw \\
obywatelskich \\
- sprzyja dyscyplinie \\
i moralnemu wy- \\
chowaniu
\end{tabular} & $\begin{array}{l}\text { - służy samorealizacji } \\
\text { (satysfakcji) i socja- } \\
\text { lizacji jednostki } \\
\text { - przynosi pracow- } \\
\text { nikowi zarobki } \\
\text { wystarczajacce na } \\
\text { "godne życie" } \\
\text { - sprzyja rozwojowi } \\
\text { cywilizacyjnemu } \\
\text { i dobrobytowi ca- } \\
\text { łego społeczeństwa } \\
\text { - nie szkodzi środo- } \\
\text { wisku naturalnemu }\end{array}$ & $\begin{array}{l}\text { - służy głównie } \\
\text { zyskom nielicz- } \\
\text { nych posiada- } \\
\text { czy kapitału } \\
\text { - często przynosi } \\
\text { szkodę pracow- } \\
\text { nikom najem- } \\
\text { nym (polega na } \\
\text { wyzysku) } \\
\text { - nieodwracalnie } \\
\text { niszczy środo- } \\
\text { wisko przyrod- } \\
\text { nicze w wyniku } \\
\text { nadmiernej } \\
\text { eksploatacji } \\
\text { zasobów natu- } \\
\text { ralnych }\end{array}$ \\
\hline \multicolumn{4}{|c|}{ domena relacji między podmiotami } \\
\hline \begin{tabular}{|l|} 
- praca w sfe- \\
rze budżeto- \\
wej (urzędy, \\
szkolnictwo), \\
opłacana \\
„z podatków \\
tych, którzy \\
ciężko pra- \\
cuja” \\
- jest podstawą \\
nieuczci- \\
wych rosz- \\
czeń wobec \\
państwa, \\
czyli źródłem \\
„przywilejów \\
socjalnych"
\end{tabular} & \begin{tabular}{|l|} 
- praca najemna u \\
prywatnego praco- \\
dawcy (na podsta- \\
wie umowy na czas \\
określony) \\
lub praca na wła- \\
sny rachunek (małe \\
przedsiębiorstwo, \\
„samozatrudnie- \\
nie”) \\
- polega na indywi- \\
dualnym, samo- \\
dzielnym wysiłku, \\
który przynosi \\
dochód jednostce, \\
niekorzystajacej \\
z pomocy państwa, \\
rodziny czy kolek- \\
tywu
\end{tabular} & $\begin{array}{l}\text { - zatrudnienie na eta- } \\
\text { cie w państwowym } \\
\text { lub prywatnym } \\
\text { przedsiębiorstwie } \\
\text { albo uprawianie } \\
\text { „wolnego zawodu” } \\
\text { - bezpieczeństwo pra- } \\
\text { cownika jest chro- } \\
\text { nione przez prawo } \\
\text { i właściwe urzedy } \\
\text { - osiagnięcia jedno- } \\
\text { stek sa zależne od } \\
\text { dorobku (pracy) } \\
\text { wielu pokoleń } \\
\text { przodków, wsparcia } \\
\text { rodziny / kolektywu } \\
\text { i całego społeczeń- } \\
\text { stwa }\end{array}$ & $\begin{array}{l}\text { - praca w prywat- } \\
\text { nych firmach } \\
\text { polegajaca na } \\
\text { wyzyskiwaniu } \\
\text { „siły roboczej” } \\
\text { przez posiada- } \\
\text { czy kapitału } \\
\text { i środków pro- } \\
\text { dukcji } \\
\text { - w konkurencyj- } \\
\text { nej gospodarce } \\
\text { „dobra pracę" } \\
\text { maja nieliczni; } \\
\text { pozostali to } \\
\text { „prekariusze” } \\
\text { lub bezrobotni } \\
\text { - państwo działa } \\
\text { na rzecz „lobby } \\
\text { pracodawców”; } \\
\text { nie chroni pra- } \\
\text { cowników }\end{array}$ \\
\hline
\end{tabular}




\begin{tabular}{|c|c|c|c|}
\hline \multicolumn{2}{|c|}{$\begin{array}{c}\text { Praca w dyskursie } \\
\text { zwolenników kapitalizmu }\end{array}$} & \multicolumn{2}{|c|}{$\begin{array}{c}\text { Praca w dyskursie } \\
\text { krytyków kapitalizmu }\end{array}$} \\
\hline $\begin{array}{c}\text { Model służący } \\
\text { identyfikacji } \\
\text { przeciwników }\end{array}$ & $\begin{array}{l}\text { Model służący } \\
\text { autoidentyfikacji }\end{array}$ & $\begin{array}{l}\text { Model służący } \\
\text { autoidentyfikacji }\end{array}$ & $\begin{array}{l}\text { Model służący } \\
\text { identyfikacji } \\
\text { przeciwników }\end{array}$ \\
\hline \multicolumn{4}{|c|}{ domena wartości } \\
\hline $\begin{array}{l}\text { - wartość he- } \\
\text { donistyczna } \\
\text { (służy indy- } \\
\text { widualnej } \\
\text { przyjemności) } \\
\text { - przymus } \\
\text { ciężkiej pracy } \\
\text { jako anty- } \\
\text { wartość (oni } \\
\text { = ludzie nie- } \\
\text { moralni, uni- } \\
\text { kający pracy, } \\
\text { bezrobotni } \\
\text { z wyboru, } \\
\text { klienci opieki } \\
\text { społecznej) }\end{array}$ & $\begin{array}{l}\text { - dobro utylitarne: } \\
\text { służy zapewnie- } \\
\text { niu dobrobytu (lub } \\
\text { przynajmniej go- } \\
\text { dziwej egzystencji) } \\
\text { jednostce, rodzinie } \\
\text { i całej społeczności } \\
\text { - wartość moralna: } \\
\text { podstawowy wy- } \\
\text { znacznik uczciwo- } \\
\text { ści pojedynczego } \\
\text { człowieka wobec } \\
\text { społeczeństwa („my } \\
\text { = ludzie ciężko pra- } \\
\text { cujący; niekorzy- } \\
\text { stający za darmo } \\
\text { z tego, co wypraco- } \\
\text { wali inni) }\end{array}$ & $\begin{array}{l}\text { - wartościowa jest } \\
\text { tylko taka praca, } \\
\text { która sprzyja do- } \\
\text { brostanowi jedno- } \\
\text { stek i społeczności } \\
\text { (my = usatysfak- } \\
\text { cjonowani człon- } \\
\text { kowie kolektywów } \\
\text { pracowniczych lub } \\
\text { kreatywni „freelan- } \\
\text { cerzy” pracujaccy } \\
\text { na rzecz wspólnego } \\
\text { dobra) } \\
\text { - stosunek do pracy } \\
\text { (zarobkowej) nie } \\
\text { jest najważniejsza } \\
\text { miara wartości czło- } \\
\text { wieka i obywatela }\end{array}$ & $\begin{array}{l}\text { - wartość instru- } \\
\text { mentalna pod- } \\
\text { porządkowana } \\
\text { bogaceniu się } \\
\text { (oni = godzacy } \\
\text { się na zniewo- } \\
\text { lenie i gotowi } \\
\text { wykorzystywać } \\
\text { innych dla wła- } \\
\text { snych korzyści } \\
\text { materialnych) } \\
\text { - miernik pozy- } \\
\text { cji społecznej } \\
\text { człowieka: bez- } \\
\text { robotni oraz } \\
\text { mający niskie } \\
\text { zarobki sa ska- } \\
\text { zani na nędzę } \\
\text { i społeczne wy- } \\
\text { kluczenie }\end{array}$ \\
\hline \multicolumn{4}{|c|}{ domena praw i powinności podmiotów } \\
\hline $\begin{array}{l}\text { - jednostka nie } \\
\text { musi pra- } \\
\text { cować i ma } \\
\text { prawo żyć na } \\
\text { koszt podat- } \\
\text { ników (pra- } \\
\text { cujacych) } \\
\text { - stosunek do } \\
\text { pracy nie jest } \\
\text { wyznaczni- } \\
\text { kiem pozycji } \\
\text { jednostki } \\
\text { w społeczeń- } \\
\text { stwie }\end{array}$ & $\begin{array}{l}\text { - praca jest obowią- } \\
\text { kiem moralnym } \\
\text { każdego dorosłego } \\
\text { (i zdrowego) obywa- } \\
\text { tela: „nikt nie ma } \\
\text { prawa żyć na koszt } \\
\text { innych” } \\
\text { - pracownicy na- } \\
\text { jemni nie powinni } \\
\text { strajkować (moga } \\
\text { poszukać innej } \\
\text { pracy) } \\
\text { - ci, którzy „daja } \\
\text { pracę” i ryzykują } \\
\text { utratę kapitału, } \\
\text { maja prawo dbać } \\
\text { głównie o własny } \\
\text { zysk i dzielić się } \\
\text { nim z innymi do- } \\
\text { browolnie (nie pod } \\
\text { przymusem pań- } \\
\text { stwa) }\end{array}$ & $\begin{array}{l}\text { - praca najemna jest } \\
\text { prawem, nie może } \\
\text { być obowiązkiem } \\
\text { obywatela } \\
\text { - zrzeszanie sie pra- } \\
\text { cowników i zbio- } \\
\text { rowe protesty } \\
\text { (w tym strajk) sa } \\
\text { legalnymi środkami } \\
\text { obrony interesów } \\
\text { pracowniczych } \\
\text { - państwo powinno } \\
\text { ustalić i egzekwo- } \\
\text { wać przestrzeganie } \\
\text { zasad bezpieczeń- } \\
\text { stwa, godności } \\
\text { i sprawiedliwego } \\
\text { wynagradzania pra- } \\
\text { cowników najem- } \\
\text { nych }\end{array}$ & $\begin{array}{l}\text { - pracownicy na- } \\
\text { jemni nie mają } \\
\text { żadnych praw } \\
\text { oprócz prawa } \\
\text { do rezygnacji } \\
\text { z pracy } \\
\text { - nikt nie ma } \\
\text { obowiazzku } \\
\text { zapewniania } \\
\text { pracy } \\
\text { - bezrobotni sa } \\
\text { „sami sobie } \\
\text { winni” (sa le- } \\
\text { niwi, „nie- } \\
\text { mobilni” lub } \\
\text { niechętni do } \\
\text { nauki) }\end{array}$ \\
\hline
\end{tabular}




\begin{tabular}{|c|c|c|c|}
\hline \multicolumn{2}{|c|}{$\begin{array}{c}\text { Praca w dyskursie } \\
\text { zwolenników kapitalizmu }\end{array}$} & \multicolumn{2}{|c|}{$\begin{array}{c}\text { Praca w dyskursie } \\
\text { krytyków kapitalizmu }\end{array}$} \\
\hline $\begin{array}{l}\text { Model służący } \\
\text { identyfikacji } \\
\text { przeciwników }\end{array}$ & $\begin{array}{l}\text { Model służący } \\
\text { autoidentyfikacji }\end{array}$ & $\begin{array}{l}\text { Model służący } \\
\text { autoidentyfikacji }\end{array}$ & $\begin{array}{l}\text { Model służący } \\
\text { identyfikacji } \\
\text { przeciwników }\end{array}$ \\
\hline $\begin{array}{l}\text { - indywidualne } \\
\text { zyski z pracy } \\
\text { i majątek } \\
\text { prywatnych } \\
\text { podmio- } \\
\text { tów moga } \\
\text { być „zabie- } \\
\text { rane” przez } \\
\text { państwo } \\
\text { („jak w ko- } \\
\text { munizmie”) } \\
\text { i rozdawane } \\
\text { niepracują- } \\
\text { cym }\end{array}$ & $\begin{array}{l}\text { - warunki pracy } \\
\text { i wynagrodzenia } \\
\text { powinny wynikać } \\
\text { z wolnej konku- } \\
\text { rencji oraz umowy } \\
\text { między pracodawca } \\
\text { a pracownikiem, } \\
\text { w która ani pań- } \\
\text { stwo, ani związki } \\
\text { zawodowe nie po- } \\
\text { winny ingerować } \\
\text { - niezdolni do pracy } \\
\text { moga oczekiwać } \\
\text { pomocy ze strony } \\
\text { rodziny i organizacji } \\
\text { dobroczynnych }\end{array}$ & $\begin{array}{l}\text { - część indywidual- } \\
\text { nego zysku z pracy } \\
\text { powinna być pobie- } \\
\text { rana i sprawiedliwie } \\
\text { dzielona przez pań- } \\
\text { stwo w celu zapew- } \\
\text { nienia ważnych } \\
\text { usług publicznych } \\
\text { oraz wyrównywania } \\
\text { różnic w poziomie } \\
\text { życia obywateli, } \\
\text { także zapewnienia } \\
\text { wsparcia tym, któ- } \\
\text { rzy nie moga praco- } \\
\text { wać }\end{array}$ & $\begin{array}{l}\text { - zdolni do pracy, } \\
\text { lecz niepracu- } \\
\text { jący nie maja } \\
\text { prawa do po- } \\
\text { mocy ze strony } \\
\text { państwa (podat- } \\
\text { ników) } \\
\text { - państwowa } \\
\text { ochrona pra- } \\
\text { cowników jest } \\
\text { niepotrzebna } \\
\text { i demoralizu- } \\
\text { jaca }\end{array}$ \\
\hline
\end{tabular}

\section{KONKLUZJA}

Zrekonstruowane wyżej modele kognitywne (ICM-y) organizują współczesny polski dyskurs o pracy toczony za pośrednictwem Internetu. Przeprowadzona analiza dowodów językowych: słów kluczy, powtarzalnych kolokacji, metafor, sentencjonalnych fraz oraz wyrażeń wartościujących i konotujących określone doświadczenie uczestników dyskursu wskazuje na silna polaryzację, która ujawnia dwie opozycyjne grupy: zwolenników kapitalizmu oraz jego krytyków. Odmienne poglądy na funkcjonowanie gospodarki dostarczaja istotnych ram interpretacyjnych decydujacych o różnym profilowaniu kategorii praca w debatach medialnych. Kontrowersyjność pojęcia wyraża się również w tym, że na modele poznawcze zbudowane wokół niego składają się nie tylko aksjomaty, z którymi grupa się identyfikuje, lecz i takie, które przypisuje swoim oponentom. ICM-y mają zarówno wartość opisowa (diagnostyczną), jak i normatywną: pozwalaja rozpoznawać i przewidywać poglądy uczestników dyskursu na inne kontrowersyjne tematy dotyczace gospodarki, np. takie jak rola państwa czy konstrukcja systemów podatkowych. 


\section{Źródla cytowanych komentarzy}

\section{- rozwiązanie skrótów nazw stron internetowych}

G-2019 - http://next.gazeta.pl/next/7,151003,24383778,26-bogaczy-ma-majatek-warty-tyle-ile-posiada-polowa-ludzkosci.html [dostęp: 21.01.2019].

G-2019a - http://next.gazeta.pl/next/7,151003,24973427,komuda-wzrost-ksenofobii-to-wina-polskich-pracodawcow-na.html\#a=88\&c=145\&s=BoxBizLink [dostęp: 8.07.2019].

In-2016 - http: / fakty.interia.pl/tylko-u-nas/news-oszukal-mnie-ronald-reagan,nId,2214857 [dostęp: 8.06.2016].

In-2018 - https:/ / praca.interia.pl/news-nawet-z-praca-nie-ma-kolaczy-ekspertna-aktualnosci-zyskuja-,nId,2743413 [dostęp: 26.12.2018].

In-2018a - https://fakty.interia.pl/swiat/news-francja-rzad-rozwazawprowadzenie-stanuwyjatkowego, nId,2707973 [dostęp: 2.12.2018].

In-2019 - https://praca.interia.pl/news-bezwarunkowy-dochod-podstawowyani-lek-ani-homeopatia, nId,3060831 [dostęp: 25.06.2019].

In-2019a - https:/ / biznes.interia.pl/wiadomosci/news/modzelewski-wyborcze-plebiscyty-zadecyduja, 2620505,4199 [dostęp: 29.06.2019].

In-2019b - https://biznes.interia.pl/wiadomosci/news/resort-rolnictwabedzie-odgornie-wyznaczac-ceny-skupu-owocow,2624411,4199 [dostęp: 29.07.2019].

KP-2017 - http:/ /krytykapolityczna.pl/swiat/fiala-praca-w-kapitalizmie/ [dostęp: 03.05.2017].

KP-2017a - http://krytykapolityczna.pl/kraj/sroczynski-sutowski-wywiad/ [dostęp: 23.12. 2017].

KP-2018 - KP-2018 - http://krytykapolityczna.pl /swiat/ue/jan-zielonka-michal-sutowski-liberalizm/ [dostęp: 30.04.2018].

KP-2018a - http://krytykapolityczna.pl/kraj/kapitalizm-jest-obrzydliwy-idoprowadza-mnie-do-placzu/ [dostęp: 10.07.2018].

W-2015 - http://wyborcza.pl/duzyformat/1,127290,17430930,_Bochniarz Etatow_nie_bedzie.html [dostęp: 18.02.2015].

W-2018- http:/ / wyborcza.pl/7,75968,23618767,czego-nie-widzi-sroczynski-gdy-zachwyca-sie-morawieckim-co.html [dostęp: 01.07.2018].

W-2019 - http://wyborcza.pl/7,75968,24377710,lewica-marzy-o-blogim-lenistwie.html [dostęp: 20.01.2019].

WP-2018 - https://wpolityce.pl/kultura/381596-pgr-obrazy-to-odtrutka-nanieslawna-arizone-dopiero-teraz-zrozumialem-dramat-tych-ludzi [dostęp: 15.02.2018].

\section{Bibliografia}

M. Czyżewski, K. Franczak, M. Nowicka, J. Stachowiak (red.), 2014, Dyskurs elit symbolicznych. Próba diagnozy, Warszawa.

M. Friedman, 2018, Kapitalizm i wolność, tłum. B. Salbut, Gliwice.

S. Jäger, 1999, Kritische Diskursanalyse. Eine Einführung, wyd. 2, Duisburg.

M. Kita, 2014, Słowa magnesy. O (nie)przewidywalnym efekcie skupiania uwagi odbiorcy na słowie w dyskursie publicznym (medialnym) [w:] K. Jachimowicz, B. Kudra, E. Szkudlarek-Śmiechowicz (red.), Słowo we współczesnych dyskursach, Łódź, s. 13-22. 
K. Kłosińska, 2016, Opozycja jako podstawowe tworzywo dyskursów politycznych [w:] B. Witosz, K. Sujkowska-Sobisz, E. Ficek (red.), Dyskurs i jego odmiany, Katowice, s. 113-120.

G. Lakoff, 1987, Women, Fire and Dangerous Things. What Categories Reveal about the Mind, Chicago.

G. Lakoff, 2017, Moralna polityka. Jak myśla liberałowie i konserwatyści, tłum. M. Szczubiałka, Warszawa.

R.W. Langacker, 1987, Foundations of cognitive grammar, t. 1: Theoretical prerequisites, Stanford.

M. Mazurkiewicz-Brzozowska, 1993, Praca. Wybrane warianty znaczenia słowa we współczesnej polszczyźnie $i$ ich struktura kognitywna [w:] J. Bartmiński, M. Mazurkiewicz-Brzozowska (red.), Nazwy wartości. Studia leksykalno-semantyczne, Lublin, s. 133-146.

SJPDor - W. Doroszewski (red.), 1958-1969, Słownik języka polskiego, t. 1-11, Warszawa.

P. Stańczyk, 2013, Człowiek, wychowanie, praca w kapitalizmie. W strone krytycznej pedagogiki pracy, Gdańsk.

J.E. Stiglitz, 2015, Cena nierówności. W jaki sposób dzisiejsze podziały społeczne zagrażaja naszej przyszłości?, tłum. R. Mitoraj, Warszawa.

G. Stötzel, M. Wengeler, 1995, Kontroverse Begriffe. Geschichte des öffentlichen Sprachgebrauchs in der Bundesrepublik Deutschland, Berlin-New York.

A. Wierzbicka, 1997, Understanding cultures through their key words, New YorkOxford.

\section{Work as a controversial notion in online debates of Poles: a linguistic reconstruction of cognitive models (on the material of statements of 2015-2019)}

\section{Summary}

The observations presented in this paper fall within the confines of a plan covering a broader scope of research on the key notions underlying the constitution and polarisation of the Polish economic discourse on popular web portals. The idealised cognitive models (ICMs) of "work", actualised in the discourse, are subject to a linguistic reconstruction and the methodological principle consists in an analysis of semantic profiles of the key symbol and recurrent collocations as well as the standard phrases invoking the identified central notion. The divergent views on the operation of the economy presented by two distinctive groups of discourse participants: advocates and critics of capitalism provide an important interpretative framework determining the diverse profiling of the category "work" in the online debate. The controversy of the notion manifests itself also in the fact that the two contradictory cognitive models built around it are composed not only of the axioms accepted by a given group but also of the ones it ascribes to their opponents.

Keywords: online economic discourse - controversial notions - ICM "work". 